\title{
PENGELOLAAN PEMBELAJARAN DI SD NEGERI 09 HILIA LAMO KAMANG HILIA KECAMATAN KAMANG MAGEK KABUPATEN AGAM
}

\section{Syukra Vadhillah}

Guru SD Negeri 22 Magek, Kecamatan Kamang Magek, Kabupaten Agam email: fsyukraf@gmail.com

\begin{abstract}
This study was purposed at identifyng the instructional management in State Primary School 09 Hilia Lamo, Kamang Magek, Agam by using qualitative approach case study. The researcher used interview, observation and documentation on collecting data. The results showed that the instructional instrument was made on vacation through workshop 3 until 4 days. The instruction was begun by flight ceremony, morning gymnastics, memorizing and reading a holy quran. The instruction was done by using various methods. To monitor the instructional process, the school gave the notice to the parents related to the students'skill. Then the teachers were also gotten the suggestion related to teaching improvement through principal's supervision at least twice a semester.
\end{abstract}

Keywords: Management, Instruction, Primary School, Kamang Magek Agam.

\section{PENDAHULUAN}

Penelitian ini berawal dari ucapan salah seorang guru yang mengajar di SD Negeri 22 Magek yang bernama Sasmia Wilda, S.Pd.I. Pernyataan tersebut dinyatakan pada peneliti pada hari Selasa, 15 Desember 2015. Beliau menyatakan bahwa pengelolaan pembelajaran di SD Negeri 09 Hilia Lamo lebih baik dan menjadi contoh bagi Sekolah Dasar lain di Kecamatan ini. Proses pembelajarannya bagus, segala administrasinya lengkap, dan teratur. Dari hal inilah menurut peneliti kajian penelitian tentang pengelolaan pembelajaran di SD Negeri 09 Hilia Lamo penting dilakukan.
Selama ini yang mejadi pokok perhatian bagi kalangan pendidik baik itu orang tua, guru maupun masyarakat Indonesia umumnya adalah hasil belajar peserta didik. Ini dibuktikan dengan pertanyaanpertanyaan yang mereka ajukan kepada peserta didik di akhir semester. "Berapa ratarata nilainya?", "Ranking berapa?”, "Siapa yang memiliki nilai tertinggi di kelas?", "Siapa yang menjadi juara umum?" dan banyak lagi pertanyaan-pertanyaan yang muncul. Pertanyaan-pertanyaan tersebut mengarah pada hasil belajar peserta didik saja. Padahal hasil belajar belum tentu menunjukkan kemampuan peserta didik 
yang sesungguhnya. Sebab, banyak hal yang dapat mempengaruhi hasil belajar peserta didik. Hal yang dapat mempengaruhi hasil belajar itu di antaranya adalah kondisi fisik ketika mengikuti ujian semester. Jika peserta didik yang mengikuti ujian dalam keadaan kurang sehat, maka otomatis ia tidak bisa berkonsentrasi secara penuh dalam menjawab soal-soal ujian yang diberikan. Sehingga hasil belajar yang ia dapatkan tidak sebagus ketika dia menjawab dalam keadaan sehat. Dengan demikian, proses pembelajaran juga penting dalam menentukan prestasi peserta didik. Hal ini sesuai dengan teori belajar kognitif yang mengatakan bahwa peserta didik memproses informasi dan pelajaran melalui upaya mengorganisir, menyimpan dan menemukan hubungan antara pengetahuan yang baru dengan yang telah ada. Teori ini juga menekankan aspek pengelolaan yang berpengaruh besar terhadap belajar.

Selain itu, dalam al-Qur'an Allah juga telah membicarakan hal itu dalam Qur'an (Surat At-Taubah, 105) dan katakanlah: "Bekerjalah kamu, maka Allah dan RasulNya serta orang-orang mukmin akan melihat pekerjaanmu itu, dan kamu akan dikembalikan kepada (Allah) Yang Mengetahui akan yang ghaib dan yang nyata, lalu diberitakan-Nya kepada kamu apa yang telah kamu kerjakan. Dari ayat tersebut dapat diketahui bahwa hasil tidak akan memungkiri usaha. Hal yang penting harus tetap berusaha dahulu. Karena tanpa usaha, semuanya tidak akan mungkin terjadi, termasuk usaha dalam belajar, proses dalam belajar.

Kemudian, teori yang telah disebutkan di atas, diperkuat oleh teori Gagne (1968) yang menyatakan bahwa belajar itu merupakan proses luas yang dibentuk oleh pertumbuhan dan perkembangan tingkah laku. Itu artinya hal terpenting dari belajar ialah proses mendapatkannya, tidak hanya hasil belajar. Setelah belajar, peserta didik memiliki pengetahuan, sikap, keterampilan dan nilai itu berasal stimulus yang berasal dari lingkungan. Lingkungan itu salah satunya ialah lingkungan sekolah formal tempat peserta didik mempelajari berbagai pengetahuan keterampilan dan nilai. Peneliti menilai SD Negeri 09 Hilia Lamo mengutamakan proses daripada hasil.

\section{PENGELOLAAN PEMBELAJARAN}

Pengelolaan pembelajaran merupakan frase yang terdiri dari dua kata yaitu pengelolaan dan pembelajaran. Menurut Depdiknas (2007), kata pengelolaan berasal dari bahasa Indonesia yaitu kelola yang mendapat akhiran -an sehingga artinya proses yang membantu merumuskan kebijaksanaan dan tujuan organisasi. Dengan adanya kegiatan 
pengelolaan maka keputusan yang baik untuk persoalan yang ada dapat ditetapkan sehingga tujuan dapat dicapai dengan baik. Sedangkan kata pembelajaran menurut Depdiknas (2007) merupakan kata yang juga berasal dari bahasa Indonesia yaitu kata belajar yang mendapat imbuhan pe-dan -an sehingga artinya adalah proses, cara, perbuatan yang menjadikan orang atau makhluk hidup belajar. Jika guru melaksanakan proses pembelajaran maka seharusnya guru berusaha membuat suasana sehingga peserta didik mau belajar dengan sendirinya.

Pada paragraf sebelum ini telah dikemukakan pengertian pembelajaran secara bahasa. Selanjutnya akan dibahas pengertian pembelajaran menurut pendapat para ahli pendidikan. Berikut ini merupakan pendapat beberapa ahli pendidikan mengenai pembelajaran, yaitu: 1) Gagne mengemukakan bahwa pembelajaran adalah seperangkat peristiwaperistiwa eksternal yang dirancang untuk mendukung beberapa proses belajar yang sifatnya internal; 2) Miarso mengatakan bahwa pembelajaran merupakan usaha pendidikan yang dilaksanakan secara sengaja dengan tujuan yang telah ditetapkan terlebih dahulu sebelum proses dilaksanakan, serta pelaksanaannya terkendali; 3) Winkel berpendapat bahwa pembelajaran adalah pengaturan dan penciptaan kondisi- kondisi ekstren sedemikian rupa, sehingga menunjang proses belajar siswa dan tidak menghambatnya (Siregar dan Nara, 2010).

Dalam dunia pendidikan, Trianto (2012) berpendapat bahwa istilah pembelajaran itu diartikan sebagai interaksi dua arah dari seorang guru dan peserta didik, di mana antara keduanya terjadi komunikasi (transfer) yang intens dan terarah menuju pada suatu target yang telah ditetapkan sebelumnya. Jadi, pengelolaan pembelajaran dapat diartikan sebagai suatu kegiatan yang dilakukan guru untuk memutuskan kebijaksanaan yang harus dilakukan pendidik agar peserta didik dapat belajar dengan sendirinya sehingga dapat mencapai tujuan dengan baik.

Untuk mencapai tujuan tersebut, guru merupakan sosok yang berperan dalam hal itu. Di antara peranan yang dijalani oleh guru adalah sebagai pengelola pembelajaran atau organisator. Sebagai pengelola, guru dituntut untuk mampu merencanakan kegiatan pembelajaran yang efektif dan efisien sehingga peserta didik mampu mencapai tujuan pembelajaran yang hendak dicapai. Jadi, intinya guru sebagai pengelola berfungsi sebagai orang yang menghantarkan peserta didik sehingga dapat mencapai tujuan pembelajaran.

Sebagai pengelola pembelajaran (learning manajer), guru berperan dalam menciptakan 
iklim belajar yang memungkinkan siswa dapat belajar secara nyaman. Melalui pengelolaan kelas yang baik guru dapat menjaga kelas agar tetap kondusif untuk terjadinya proses belajar seluruh siswa. Dalam melaksanakan pengelolaan pembelajaran, ada dua macama kegiatan yang harus dilakukan yaitu mengelola sumber belajar dan melaksnakan peran sebagai sumber belajar itu sendiri. Secara umum ada 4 fungsi guru sebagai pengelola pembelajaran, yaitu 1) perencanaan; 2) pengorganisasian; 3) pelaksanaan; dan 4) pengawasan.

Menurut Permendiknas (2007), Perencanaan proses pembelajaran meliputi silabus dan rencana pelaksanaan pembelajaran (RPP) yang memuat identitas mata pelajaran, standar kompetensi (SK), kompetensi dasar $(\mathrm{KD})$, indikator pencapaian kompetensi, tujuan pembelajaran, materi ajar, alokasi waktu, metode pembelajaran, kegiatan pembelajaran, penilaian hasil belajar, dan sumber belajar. Sebagai pengelola pembelajaran, guru memiliki fungsi untuk merencanakan tujuan pembelajaran yang akan dicapai. Karena tanpa tujuan, suatu pekerjaan tidak akan berjalan dengan baik dan terarah. Kemudian, guru merencanakan hal yang akan dilaksanakan untuk mencapai tujuan tersebut. Perencanaan itu meliputi memperkirakan tuntutan dan kebutuhan, mengembangkan kurikulum seperti membuat silabus dan perangkat pembelajaran lainnya. Selain itu, dalam fungsi ini guru dituntut untuk menentukan topik-topik yang akan dipelajari siswa, menentukan alokasi waktu pembelajaran untuk tiap-tiap materi pelajaran yang akan dipelajari. Setelah menentukan materi dan waktu yang akan digunakan, maka guru juga berkewajiban menentukan sumber belajar yang diperlukan.

Setelah dilakukan perencanaan, tentu dilanjutkan dengan pengorganisasian. Fungsi pengorganisasian melibatkan penciptaan lingkungan pembelajaran yang kondusif secara sengaja serta melakukan pendelegasian tanggungjawab dalam rangka mewujudkan tujuan pembelajaran yang telah ditetapkan. Dalam hal ini juga dilakukan pengaturan sumber, alat, dan sarana pembelajaran yang ada dan sesuai dengan materi pelajaran yang telah ditetapkan. Pengaturan tersebut bertujuan untuk menciptakan siswa belajar secara individual. Menurut Sanjaya (2011), untuk mencapai tujuan tersebut, tentu memerlukan pengertian dan perhatian yang mendalam terhadap siswa secara mendalam. Adalah fungsi guru untuk mengatur dan menghubungkan berbagai jenis sumber belajar sehingga tujuan pembelajaran yang direncanakan tersebut terwujud dengan cara yang paling efektif dan efisien.

Setelah dilakukan pengorganisasian, dilanjutkan dengan pelaksanaan 
pembelajaran yang merupakan implementasi dari RPP yang telah dirancang oleh guru yang bersangkutan. Pelaksanaan pembelajaran meliputi kegiatan pendahuluan, kegiatan inti dan kegiatan penutup. Terakhir, pengawasan yang menurut Sanjaya (2011) fungsi mengawasi bertujuan untuk mengusahakan peristiwa-peristiwa yang sesuai dengan rencana yang telah disusun. Tugas guru dalam mengawasi ini adalah melakukan penilaian dan peninjauan terhadap peserta didik dalam mencapai tujuan pembelajaran. Jika peserta didik belum mencapai tujuan pembelajaran yang ditetapkan maka guru bertugas untuk mengatur kembali kegiatan pembelajaran yang akan dilaksanakan di masa yang akan datang. Kegiatan itu bisa berupa remedial bagi yang belum mencapai tujuan pembelajaran dan pengayaan bagi peserta didik yang mencapai kesempurnaan tujuan pembelajaran. Hal-hal yang termasuk dalam kegiatan pengawasan ini adalah 1) pelaporan berupa hasil kegiatan pemantapan, supervisi dan evaluasi proses pembelajaran; dan 2) tindak lanjut yang meliputi penguatan dan penghargaan diberikan kepada guru yang telah memenuhi standar; teguran yang bersifat mendidik kepada guru yang belum memenuhi standar; dan memberikan kesempatan kepada guru untuk mengikuti pelatihan.

\section{METODE PENELITIAN}

Adapun metode yang digunakan dalam penelitian ini adalah penelitian kualitatif. Menurut Arikunto (1993) penelitian kualitatif adalah penelitian yang bertujuan untuk menggambarkan apa adanya tentang sesuatu atau keadaan. Jenis penelitian ini dipilih karena memang penelitian ini dilakukan untuk mengetahui fenomena yang ada sebenarnya di lapangan tanpa adanya hal yang dibuat-buat atau dikondisikan oleh peneliti sebagaimana mestinya. Penelitian ini dilakukan untuk mengetahui bagaimana proses pembelajaran yang berlangsung sehingga visi dan misi sekolah dapat dicapai dengan baik.

Informan adalah orang yang mengerti tentang hal yang diteliti dan bersedia memberikan informasi tentang hal yang diteliti tersebut. Informan dalam penelitian kualitatif juga dapat disebut dengan sampel sumber data. Sumber data yang digunakan bersifat snowball sampling. Menurut Arikunto (2010) snowball sampling artinya peneliti mencari dari informan tersebut, peneliti mencari subjek-subjek lain secara terus-menerus sampai peneliti merasa jenuh karena sudah tidak menemukan lagi subjek yang tepat. Dalam snowball sampling informan dipilih langsung sesuai dengan maksud dan tujuan penelitian yang dilakukan. Jadi, peneliti akan berhenti 
melakukan pengumpulan data dan informasi jika informasi atau data yang diperoleh dari orang-orang yang dianggap memenuhi syarat memiliki kesamaan data. Dan peneliti tidak menemukan lagi subjek atau informan lain yang patut dijadikan sumber data. Jika penelitian tentang pengelolaan pembelajaran maka yang menjadi informan kunci ialah kepala sekolah dan guru.

Untuk mengumpulkan data, peneliti menggunakan wawancara, observasi dan dokumentasi. Dalam hal wawancara, peneliti mewawancarai Kepala Sekolah dan 2 orang guru kelas. Kemudian dalam dokumentasi, data yang diambil ialah foto visi misi dan tata tertib sekolah. Peneliti merekam kegiatan wawancara dalam bentuk video yang digunakan sebagai penguat data sekaligus bukti bahwa memang penelitian itu dilakukan.

\section{HASILPENELITIAN DAN PEMBAHASAN}

Pengelolaan pembelajaran yang dilakukan di SD Negeri 09 Hilia Lamo Kecamatan Kamang Magek ialah sebagai berikut. Peneliti uraikan terkait proses perencanaan, pengorganisasian, pelaksanaan, dan pengawasan.

Untuk melaksanakan pembelajaran di kelas, pendidik sudah memiliki persiapan berupa beberapa perangkat pembelajaran penting seperti silabus, RPP, KKM dan media pembelajaran. Untuk menghadapi itu semua, guru SD Negeri 09 Hilian Lamo mempersiapkannya sebelum tahun ajaran baru dimulai. Hal ini tergambar dari pernyataan dari Kepala Sekolah (Darnelis) (30 Desember 2015) “...ada lokakarya sebelum akbir tahun. Lokakarya diadakan sekali setahun selama 3 hari. Itu dari ibuk-ibuk semua." Hal itu didukung oleh pernyataan seorang guru Hertati (30 Desember 2015) "jadi kan ada lokakarya di akhir semester. Lokakarya inilah yang jadi sarana untuk pembuatannya. Lokakarya itu difokuskan untuk itu". Dalam lokakarya itu, semua guru merumuskan, memusyawarahkan perangkat pembelajaran berupa silabus, RPP dan lain sebagainya.

Kegiatan lokakarya ini berlangsung ketika libur semester 2, 3 atau 4 hari. Sesuai dengan pengakuan dari Hertati (30 Desember 2015) “...pokoknya 3 atau 4 hari, kadang-kadang tidak berturut-turut." Dari pernyataan itu dapat diketahui bahwa guru-guru SD Negeri 09 Hilia Lamo benar-benar mempersiapkan segala macam persiapan untuk mengajar. Bahkan libur semester pun dipakai untuk mengerjakan tugas administrasi sekolah. Kemudian jika terdapat guru yang belum menyiapkan perangkat sementara pembelajaran sudah dimulai, maka guru yang bersangkutan diberi peringatan dengan baik oleh Kepala Sekolah dan dibantu dalam penyelesaiannya. 
Jika memang guru tersebut kurang mampu dalam membuatnya.

Pada kegiatan pengorganisasian dilakukan dengan membuat semua perangkat yang harus ada. Kemudian mengumpulkannya di awal tahun ajaran. hal ini sesuai dengan pernyataan Hartati (30 Desember 2015), "pokoknya persiapan harus ada, standby pokoknya awal tahun ajaran sudah pakai perangkat pembelajaran". Dalam pengumpulan itu sudah ditentukan berbagai media, alat dan sumber yang akan digunakan dalam melaksanakan pembelajaran di kelas.

Setelah segala perangkat persiapan untuk mengajar selesai, selanjutnya proses implementasi atau biasa dikenal dengan pelaksanaannya. Pelaksanaan pembelajaran di SD Negeri 09 Hilia Lamo dimulai dengan kegiatan pagi. Kegiatan ini memiliki keunikan dalam melaksanakan acara pagi hari. Mulai hari Senin diisi dengan upacara bendera kemudian Selasa diawali dengan senam pagi. Kemudian hari Rabu diisi dengan pembacaan kali-kali dan tahfiz ayat pendek. Kegiatan ini dilakukan dengan berbaris di halaman sekolah, kemudian dipimpin oleh seorang peserta didik lalu membaca kali-kali dan ayat pendek secara bersamasama. Hal ini sesuai dengan ungkapan Kepala Sekolah (Darnelis) (12 Januari 2016) yaitu "....kami baris di halaman, bel berbunyi tujuh seperempat, baris siap, bagi yang memimpin kali-kali ada seperempatjam, yang memimpin hafis ada seperempat jam". Kegiatan ini dilakukan selama 15 menit sesuai dengan yang dikatakan oleh Kepala Sekolah. Selanjutnya hari Kamis, mereka awali dengan kegiatan menyanyikan lagu nasional di halaman sekolah. Kemudian hari Jum'at ada kegiatan keagamaan selama 1 jam pelajaran. Ini berdasarkan ungkapan seorang guru kelas yang mengajar kelas 6 Nofianti (12 Januari 2016), “...kalau yang tadi tu kultum kami mulai jam 7 sepuluh sampai jam 8 lewat 5 baru masuk kelas". Jadi memang kegiatan keagamaan ini disediakan waktu selama 1 jam mata pelajaran untuk melaksanakannya. Berbagai hal keahlian dan bakat peseerta didik ditampilkan, sehingga namanya bukan kultum akan tetapi kegaitan keagamaan. Berikut pernyataan Nofianti (12 Januari 2016) mengenai hal ini, “...jadi namanya kalau di kami kegiatan keagamaan bukan kultum". Setelah itu, hari Sabtu diadakan senam pagi lagi.

Setelah kegiatan di luar kelas sebelum masuk jam belajar itu dilakukan, semua murid yang berbaris itu masuk kelas sambil bersalaman degan semua guru. Berdasarkan ungkapan Nofianti (12 Januari 2016) berikut ini, “...pas kegiatan di luar guru sama anak bersalaman, salaman semuanya trus masuk kelas". Kemudian dalam kelas sebelum belajar ada lagi kegiatan sebelum 
belajar yaitu tadarus selama 20 menit. Jadi mulai belajarnya jam 07.50. Karena jam pelajaran terpakai selama 20 menit, maka untuk menggantinya jam istirahat dan jam pulang diundur pula. Biasanya peserta didik diizinkan istirahat jam 09.50 karena ada kegiatan tersebut, maka diundur menjadi jam 10.00. Kemudian untuk jam pulang awalnya jam 12.05 diundur menjadi jam 12.15. Hal ini berdasarkan pengakuan dari Nofianti (12 Januari 2016), “biasanya kan kalau masuk 07.30 kan istirahatnya pukul sepuluh kurang sepuluh kami istirahatnya jam sepuluh sampai jam sepuluh tiga puluh. Nanti pulangnya kalau di jadwal sebenarnya kan jam 12 lewat 5, jadi nambah lagi 10 menit, nanti jam 12.15". Akan tetapi hal ini kurang sesuai dengan tata tertib yang ditempel di dinding luar ruang majelis guru. Tata tertib tersebut adalah sebagai berikut.

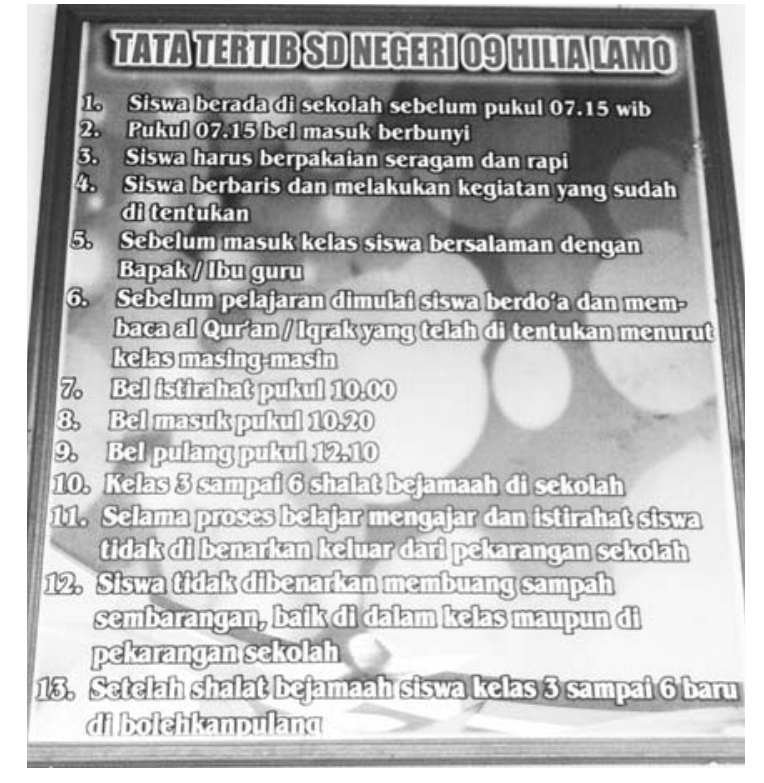

Gambar: Tata Tertib SD Negeri 09 Hilia Lamo
Walaupun demikian, pelaksanaan di lapangan hampir 100\% sudah sesuai dengan tata tertib yang telah ditetapkan bersama personil SD Negeri 09 Hilia Lamo. Hanya saja menit jam pulangnya yang ditambah selama 5 menit. Menambah menit untuk jam pelajaran itu lebih baik daripada menguranginya.

Untuk kegiatan setelah pulang sekolah, peserta didik diarahkan untuk shalat berjama'ah di mushala. Kegiatan ini diikuti oleh peserta didik mulai dari kelas 3 hingga kelas 6. Dalam hal ini kelas 3 mendapatkan tambahan jam belajar dari sekolah, walaupun dalam formalitas ketentuan dari pemeritah kelas 3 ini pulangnya jam 11.30. Itulah istimewanya di sekolah ini, banyak penambahan jam yang tujuannya untuk kebaikan peserta didik itu sendiri.

Kemudian untuk pelaksanaan pembelajaran di kelas, guru memakai berbagai metode pembelajaran seperti ceramah, diskusi, pemberian tugas dan sebagainya. Hal ini disebutkan oleh Darnelis (2015) pada peneliti bahwa pembelajaran yang dilaksanakan guru-guru di kelas itu bervariasi mulai dari ceramah, diskusi, pemberian tugas dan latihan. Hal ini juga didukung dengan menggunakan media seperti infocus atau gambar agar pembelajaran lebih menarik dan mudah diingat oleh peserta didik. 
Setelah pelaksanan atas perencanaan yang telah dibuat oleh para pendidik khususnya guru, maka dilakukanlah penilaian atas usaha pelaksanaan itu. Penilaian itu biasa disebut dengan evaluasi. Untuk mengukur kemampuan peserta didik dilakukan UH yaitu ulangan harian, kemudian MID yaitu ujian tengah semester kemudian ujian semester. UH dilakukan setelah selesai KD tertentu. Hal ini berdasarkan pernyataan Hartati (2015) bahwa ulangan harian dilaksanakan setiap selesai $1 \mathrm{KD}$ atau beberapa KD atau setiap 1 bab pelajaran. Berbeda sedikit dengan kelas 6, karena materinya memang harus selesai diajarkan pada semester 1, maka UH-nya lebih sering dibandingkan dengan kelas lain. Paling tidak sekali 2 minggu mereka ulangan. Ini sesuai dengan pengakuan Nofianti (12 Januari 2016) sebagai pengampu kelas 6 di sekolah itu. Beliau mengatakan, “...ini khusus kelas 6 ya, biasanya materi ibu tu kan sampai semester 1 itu biasanya diusahakan selesai semua. Jadi tidak sama dengan kelas lain. Jadi rata-rata kalau UH sekali 2 minggulah. 2 minggu itu minimalnya harus selesai 1 pokok bahasan". Kemudian ujian semesternya berasal dari kecamatan.

Kemudian kegiatan terakhir dalam pengelolaan pembelajaran ialah pengawasan. Dalam hal ini guru bertugas melaporkan hasil belajar peserta didik. Untuk rapor MID dibuat oleh TU kemudian dberikan kepada orang tua peserta didik di hadapan peserta didiknya. Hal ini diungkapkan oleh Kepala Sekolah (Darnelis) (20 Januari 2016), “...ujian MID dikasih raport dijemput orang tua". Kemudian pernyataan ini didukung oleh Nofianti (20 Januari 2016), "kalau di sini biasanya walaupun UTS tetap dipanggil orang tuanya". Hal ini bertujuan untuk memperingatkan orang tua peserta didik mengenai kemampuan dan prestasi yang dimiliki oleh peserta didik. Mungkin ada hal-hal yang perlu diperbaiki untuk melanjutkan pembelajaran selanjutnya. Sesuai dengan pernyataan Nofianti (20 Januari 2016), bahwa pada penerimaan rapor UTS, orang tua peserta didik dipanggil agar dapat disampaikan keadaan peserta didik yang sebenarnya.

Menjelang penerimaan rapor bagi peserta didik, gurupun dinilai oleh Kepala Sekolah dalam hal mengajar. Kegiatan ini biasanya dilakukan setiap bulan oleh Kepala Sekolah minimal 2x dalam 1 semester. Kegiatan ini dinamakan dengan supervisi. Hasilnya langsung diberitahu oleh Kepala Sekolah kepada guru yang bersangkutan. Berikut ungkapan Hartati (20 Januari 2016), “... misalnya kurang bagus. Yaa langsung, sudah disupervisi langsung dibicarakan beliau, beliau katakan langsung. Ndak dinantian lo masuak ruangan baliau, indaaak. Karena kepala sekolah orangnya fair, gak pakai formal- 
formalan. Nanti dikomentari, yang ini dihapus yang ini ditambah, yang ini dah bagus". Dari pernyataan tersebut dapat diketahui bahwa kegiatan supervisi ini dilakukan untuk memperbaiki cara guru mengajar. Jika terdapat kekurangan dalam mengajar, Kepala Sekolah langsung memberikan informasi dan masukan kepada guru yang bersangkutan. Secara tidak langsung, Kepala Sekolah telah memakai prinsip keterbukaan antara atasan dan bawahan. Hal ini juga diucapkan oleh Darnelis (20 Januari 2016) selaku Kepala Sekolah sebagai berikut "yang penting di ibuk yo, kerjasama, terbuka" Inilah beberapa keunggulan sekolah ini di bidang pengelolaan pembelajaran.

Pelaksanaan pembelajaran di SD Negeri 09 Hilia lamo memang benar baik menurut peneliti. Sebab terdapat berbagai hal penambahan kegiatan yang sangat bermanfaat untuk peserta didik. Semua itu bertujuan untuk mengembangkan potensinya, mengasah berbagai minat dan bakatnya. Namun hal tersebut berhubungan dengan waktu peserta didik. Dalam aturannya peserta didik bisa pulang jam 11.30 menjadi jam 13.00. Kegiatan peserta didik pada jam 14.00 ialah mendalami ilmu agama dan al-Qur'an di MDA atau TPA. Ketika pulang terlambat dari jam awalnya, tentu ia akan mengalami kesulitan dalam transportasi maupun dalam hal istirahat. Hal ini ditunjukan pada peserta didik yang bertempat tinggal jauh dari sekolah dan jauh dari MDA atau TPA tempat ia menuntut ilmu. Ini perlu dipertimbangkan oleh pihak sekolah.

Pengelolaan pembelajaran di SD Negeri 09 Hilia Lamo selaras dengan penelitian yang dilakukan oleh Mal, Tripathy dan Bikash (2013). Penelitian tersebut menerangkan bahwa kualitas peserta didik dapat ditingkatkan melalui belajar virtual. Belajar virtual tersebut mengajarkan peserta didik untuk mengatur belajar yang baik dengan cara yang lebih efektif, efisien sehingga tujuan pembelajaran tercapai dengan baik dibuktikan dengan kualitas. Selain itu, penelitian pengelolaan pembelajaran di SD Negeri 09 Hilia Lamo ini juga didukung oleh penelitian yang dilakukan oleh Marasabessy (2012) yang menyebutkan bahwa dalam pengelolaan pembelajaran dibutuhkan sikap profesional guru. Hal ini sesuai dengan yang dikakukan kepala sekolah yang mampu membuat peraturan dan menambah jam pelajaran dan dipatuhi oleh semua warga sekolah. Kemudian penelitian pengelolaan pembelajaran di SD Negeri 09 Hilia Lamo ini juga didukung oleh penelitian yang dilakukan oleh Hayati (2012) yang juga mengungkapkan bahwa pengelolaan pembelajaran dilakukan mulai dari perencanaan, pengorganisasian, pelaksanaan dan pengawasan. 


\section{KESIMPULAN}

Perencanaan pembelajaran dilakukan dengan membuat perangkat pembelajaran pada waktu libur melalui kegiatan lokakarya selama 3 atau 4 hari. Pelaksanaan pembelajaran diawali dengan berbagai kegiatan sebelum masuk kelas. Kegiatan itu dimulai dari upacara bendera, senam pagi, membaca hafalan kali-kali dan ayat pendek, menyanyikan lagu nasional, dan kegiatan keagamaan. Setelah masuk lokal, peserta didik diarahkan untuk membaca ayat al-Qur'an atau biasa disebut dengan tadarus. Kemudian pelaksanaan pembelajaran dilakukan dengan berbagai metode. Kemudian terdapat kegiatan sepulang sekolah yaitu shalat berjama’ah, dan juga terdapat penambahan jam untuk kelas 3 yang awalnya pulang jam 11.30 menjadi jam 13.00, sama dengan kelas tinggi.

Evaluasi pembelajaran dilakukan dengan melaksanakan UH, ujian MID dan ujian semester. Pemanatauan pembelajaran dilakukan dengan memberikan rapor hasil belajar peserta didik setelah ujian MID kemudian memberikan peringatan pada orang tuanya mengenai kemampuan dan prestasi yang dimilikinya. Lalu arahan dan masukan juga disampaikan pada guru yang mengajar mengenai cara mengajar yang kurang tepat, hal yang harus diperbaiki dan yang perlu ditambah dalam pembelajaran. Hal ini dilakukan melalui kegiatan supervisi Kepala Sekolah minimal 2x dalam 1 semester.

\section{KEPUSTAKAAN ACUAN}

Arikunto, Suharsimi. (1993). Manajemen Penelitian. Jakarta: Rineka Cipta. (2010). Prosedur Penelitian. Jakarta: PT Rineka Cipta.

Departemen Agama RI. (2005). Al-Quran dan Terjemahan. Bandung: Diponegoro.

Depdiknas. (2007). Kamus Besar Bahasa Indonesia Edisi 3. Jakarta: Balai Pustaka. Gagne, Robert M. (1968). "Contributions of Learning to Human Development". Psychological Review 75.3 (1968): 177.

Hayati, Wiwik Nurul. (2012). "Pengelolaan Pembelajaran Tematik di SD Djama'atul Ichwan”. Tesis Universitas Muhammadiyah Surakarta Tahun 2012.

Mal, Sibsankar. Tripathy, Sandip. dan Bikash, Ghosh. (2013) "Long Term Quality Enhancement and Learning Management through Virtual Teaching in Higher Education in Paschim Medinipur District". Journal of Research \& Method in Education, Vol 1, 30-36, 2013.

Marasabessy, Apridayani. (2012). "Analisis Pengelolaan Pembelajaran yang Dilakukan Oleh Guruyang Sudah Tersertifikasi dan yang Belum Tersertifikasi Pada Pembelajaran IPA di Kelas V Sekolah 
Dasar”. Jurnal Penelitian Pendidikan 13 Tahun 2012 7-13.

Miarso, Yusufhadi. (1984). Teknologi

Komunikasi Pendidikan, Pengertian dan Pengembangannya, Media Pembelajaran. Jakarta: Rajawali.

Peraturan Menteri Pendidikan Nasional Republik Indonesia Nomor 41 Tahun 2007 tentang Standar Proses untuk Satuan Pendidikan Dasar dan Menengah.

Sanjaya, Wina. (2011). Kurikulum dan Pembelajaran: Teori dan Praktik
Pengembangan Kurikulum Tingkat Satuan Pendidikan (KTSP). Jakarta: Kencana Prenada Media Group.

Siregar, Eveline dan Nara, Hartini. (2010). Teori Belajar dan Pembelajaran. Bogor: Ghalia Indonesia.

Trianto. (2012). Mendesain Model Pembelajaran Inovaif Progresif: Konsep, Landasan, dan Implementasinya pada Kurikulum Tingkat Satuan Pendidikan(KTSP). Jakarta: Kencana Prenada Media Group. 